\title{
Sources and notes
}

Jonathan Spence's The Search for Modern China is rightly considered an indispensable resource for those looking to make sense of the country's recent past; it was a regular point of reference during the course of my writing. China: A Cultural and Historical Dictionary, edited by Michael Dillon, The Cambridge Encyclopedia of China, The Oxford Illustrated History of Modern China, and Endymion Wilkinson's exhaustive Chinese History: A New Manual were also kept close at hand to assist with general queries.

\section{Introduction}

I Jie 街 is often also translated as 'avenue'.

2 At the historical moments when Beijing was replaced as the capital, it was renamed 'Beiping' or 'Northern Peace'.

3 Edgar Snow, Red Star Over China (London: Grove Press, 2018), I5I. Mao was, however, impressed by the beauty of the city: 'In the parks and the old palace grounds I saw the early northern spring, I saw the white plum blossoms flower while the ice still held solid over the North Sea. I saw the willows over Pei Hai [Bei Hai] with the ice crystals hanging from them and remembered the description of the scene by the T'ang poet Chen Chang, who wrote about Pei Hai's winter-jeweled trees, looking "like ten thousand peach trees blossoming." The innumerable trees of Peking aroused my wonder and admiration'. Snow, Red Star, I52.

4 See Shuishan Yu, Chang'an Avenue and the Modernization of Chinese Architecture (Seattle: University of Washington Press, 2012) for more on this idea. Professor Yu's volume on the relationship between ideology and architecture on Chang'an Jie is comprehensive and fascinating.

5 M.A. Aldrich, The Search for a Vanishing Beijing: A Guide to China's Capital Through the Ages (Hong Kong: Hong Kong University Press, 2006), 70. 


\section{Sources and notes}

6 Quoted in Jasper Becker, City of Heavenly Tranquillity: Beïing in the History of China (Oxford: Oxford University Press, 2008), 39.

7 Alexander Michie, The Siberian Overland Route from Peking to Petersburg (London: John Murray, i864), 32.

8 David Strand, Rickshaw Beijing: City People and Politics in the I920s (Berkeley and Los Angeles: University of California Press, I989), 2 I.

9 Ellen La Motte, Peking Dust (New York: The Century Co., I9I9), I7.

Io Simone de Beauvoir, The Long March: An Account of Modern China, trans. Austryn Wainhouse (London: Phoenix Press, 200I), I5-16.

\section{1}

I 'Shougang Transforms Caofeidian', China.org.cn, July 2007, www.china.org. cn/english/China/216873.htm. Accessed 4January 2019.

2 'Big Beijing Steel Maker Cuts Production to Help Reduce Pollution for Olympics', New Tork Times, I4 July 2008, www.nytimes.com/2008/o7/I4/ business/worldbusiness/I 4iht-shougang.I.I4477923.html. Accessed 4 January 2019 .

3 WangJun, Beijing Record: A Physical and Political History of Planning Modern Beïing (Singapore: World Scientific Publishing Company, 2011), 85 \& 88.

4 Wang Yi, A Century of Change: Beijing's Urban Structure in the 2oth Century (Berlin: Springer, 2016), 34 .

5 Frank Dikötter, Mao's Great Famine: The History of China's Most Devastating Catastrophe, 1958-62 (London: Bloomsbury, 2010), 57.

6 Zhou Xun, Forgotten Voices of Mao's Great Famine, 1958-1962: An Oral History (New Haven: Yale University Press, 2013), Iog.

7 Zhou, Forgotten Voices, i Io.

8 Zhou, Forgotten Voices, ino-in.

9 Percy Cradock, 'Interview with Sir Percy Cradock', interview by Malcolm McBain, 1997, Churchill Archives Centre, British Diplomatic Oral History Programme, DOHP.

Io Zhou, Forgotten Voices, I I4.

II ‘首钢工人用镜头记录激情燃烧的钢铁年代', People.com.cn, September II, 20I I, http://history.people.com.cn/GB/I988Ig/2I7098/I6I83095.html. Accessed 4 January 2019.

I2 “首钢正式完成搬迁治理 有 90 年历史的’钢城’光荣退役, China.com.cn, I3 January 20II, www.china.com.cn/economic/txt/20II-OI/I3/content_2I733 279.htm. Accessed 4January 20i9.

I3 Jonathan Watts, 'Beijing Goes for Green with Olympic Clean-Up', The Guardian, I9 July 2008, https://www.theguardian.com/environment/2008/ jul/ıg/pollution.china. Accessed 4January 2019.

I4 David Stanway, Stian Reklev and Kathy Chen, 'Beijing Govt, Shougang to Set up Fund to Redevelop Old Steel Mill Site', Thomson Reuters Foundation, 


\section{Sources and notes}

26 September 2014, http://news.trust.org/item/20140926ogo707-rlxg9/. Accessed 4January 2019.

\section{2}

I Lewis Mumford, The City in History: Its Origins, Its Transformations, and Its Prospects (New York: Penguin, i96i), 553.

2 Mumford, The City in History, 581.

3 Quoted in Rusty Monhollon, ed. Baby Boom: People and Perspectives (Santa Barbara: ABC-CLIO, 2010), I6o.

4 World Bank, East Asia's Changing Urban Landscape: Measuring a Decade of Spatial Growth (Washington D.C.: World Bank, 2015), 53.

5 See the IBM Global Commuter Pain Survey, 20r I and 'Commuting Time in Capital Averages 97 Minutes', China Daily, 24 November 2014, www.chi nadaily.com.cn/china/20I4-I I/24/content_I896789r.htm. Accessed 4 January 2019. Beijing's local government responded to this report by promising to reduce the average length of commutes within the Fifth Ring Road, which orbits the city's periphery and cuts through the heart of Shijingshan, to sixty minutes by 2020 .

6 '城市异化排行榜', New Weekly, 22 August 2013, www.neweekly.com.cn/ article/I03107. Accessed 4January 2019.

7 Zhang Wumao, 'Beijing Has 20 Million People Pretending to Live Here', Whatsonweibo.com, trans. Manya Koetse, July 26 20I7, https://wrew.whatsonweibo. com/beïing-20-million-people-pretending-live-full-translation. Accessed 4 January 2019.

8 Tom Miller, China's Urban Billion: The Story behind the Biggest Migration in Human History (London: Zed Books, 2012), Kindle edition, location I655.

9 David Kidd, Peking Story (London: Eland, I988), 37.

io Wang, Beijing Record, I5.

I I Beijing Park Underscores Piracy Battle, Analysts Say', $C \mathcal{N N}, 24$ May 2007, https://web.archive.org/web/20070524234252/http://edition.cnn.com/ 2007/BUSINESS/05/Io/china.copying.ap/. Accessed 4 January 2019.

\section{4}

For biographical detail, this chapter draws particularly on Jürgen Domes, Peng Te-Huai: The Man and the Image.

I See Chang-Tai Hung, Mao's New World: Political Culture in the Early People's Republic (Ithaca: Cornell University Press, 201 I), 224-232.

2 The ashes of the last Qing Emperor, Puyi, had also been interred at Babaoshan after his death in 1967; they were moved to a new cemetery near the Western Qing tombs in I995, following a deal made with Puyi's widow.

3 Snow, Red Star, 265.

4 Domes, Peng Te-Huai, 44. 


\section{Sources and notes}

5 Frederick C. Teiwes, 'Peng Dehuai and Mao Zedong', The Australian Fournal of Chinese Affairs, no. I6 (I986): 8I-98.

6 Jung Chang and Jon Halliday, Mao: The Unknown Story (London: Vintage, 2007), I44.

7 Alexander V. Pantsov and Steven I. Levine, Mao: The Real Story (New York: Simon and Schuster, 2012), Kindle edition, location 8899.

8 Christopher Howe and Kenneth R. Walker, eds. The Foundations of the Chinese Planned Economy: A Documentary Survey, 1953-65 (London: Macmillan, I989), 88.

9 Domes, Peng Te-Huai, 83 .

Io Domes, Peng Te-Huai, 94 .

I I Roderick MacFarquhar, ed. The Politics of China: The Eras of Mao and Deng (Cambridge: Cambridge University Press, I997), I04-106.

I2 Yan Jiaqi and Gao Gao, Turbulent Decade: A History of the Cultural Revolution, trans. D.W.Y. Kwok (Honolulu: University of Hawai'i Press, I996), 2 I4.

I3 Jung Chang, Wild Swans: Three Daughters of China (London: HarperCollins, 2003), Kindle edition, location $75^{22 .}$

I4 Domes, Peng Te-Huai, I24.

I5 Domes, Peng Te-Huai, 26.

i6 Domes, Peng Te-Huai, I27.

I See Yu, Chang'an Avenue, I3-34.

2 They also obstructed the free and safe flow of traffic. See Wang, Beijing Record, 24I-242.

3 Peng Dehuai who, until that summer and the Lushan Conference, had been in charge of the armed forces and thus would have ordinarily overseen the parade, had been replaced by Lin Biao.

$4 \mathrm{Yu}$, Chang'an Avenue, 23.

5 Jacques Marcuse, The Peking Papers: Leaves from the Notebook of a China Correspondent (London: Arthur Baker, I967).

6 Alexander C. Cook, The Cultural Revolution on Trial: Mao and the Gang of Four (Cambridge: Cambridge University Press, 2016), i6.

\section{6}

I This site is, according to sources on the Chinese internet, the People's Liberation Army Logistics Command College.

2 Kidd, Peking Story, 37.

3 Stephen G. Haw, Beijing: A Concise History (Abingdon: Routledge, 2007), I I.

4 Wang, Beijing Record, i I4.

$5 \mathrm{Yu}$, Chang'an Avenue, 8I. 


\section{Sources and notes}

I In 2018, the North Korean leader Kim Jong-un would stay at Diaoyutai the latest historic visitor to the guesthouse.

2 Henry Kissinger, On China (New York: Penguin, 201 I), 255.

3 Ross Terrill, The White-Boned Demon: A Biography of Madame Mao Zedong (New York: William Morrow, I984), 385.

4 Cook, The Cultural Revolution on Trial, 74.

5 Frank Dikötter, The Cultural Revolution: A People's History, 1962-1976 (London: Bloomsbury, 2016), $5^{6}$.

6 Dikötter, The Cultural Revolution, 74.

7 Kidd, Peking Story, i96. The crematorium was that at Babaoshan.

8 Geremie R. Barmé, 'Beijing's Bloody August', Danwei, www.danwei.org/ Beijings\% 20Bloody\% 20August.pdf. Accessed 4 January 2019.

9 Terrill, The White-Boned Demon, 375.

Io Fox Butterfield, 'Revenge Seems to Outweigh Justice at Chinese Trial', New Tork Times, 5 December, I980.

Stephen G. Haw's Beijing: A Concise History is, as its title suggests, a good, brief introduction to the city's development. Becker's City of Heavenly Tranquillity, Jaivin's Beijing and Aldrich's The Search for a Vanishing Beijing all delve more deeply into the history of the city.

I The dawuding style never entirely disappeared however; a particularly startling modern example can be seen at the city's West Railway Station, which looks as though a tiered temple roof was one day simply craned on to the top of its bland modern towers.

2 John Man, The Mongol Empire: Genghis Khan, His Heirs and the Founding of Modern China (London: Corgi, 2015), 63.

3 Though Beijing's name translates as 'Northern Capital', the Khitans, another nomadic group from the north - demonstrating that geography is always relative - referred to the city as their 'Southern Capital', as it sat to the south of the lands they dominated.

4 Though the city would continue as co-capital of the nation for a number of years afterwards, until in I44I Beijing became the undisputed capital.

5 Jonathan D. Spence, The Gate of Heavenly Peace: The Chinese and Their Revolution, I895-I980 (Harmondsworth: Penguin, I982), 37.

6 Later the same figures would argue that perhaps Shanghai was the preferable choice.

7 Derk Bodde, Peking Diary: A Year of Revolution (New York: Henry Schuman, I950), 9 . 


\section{Sources and notes}

For a broad understanding of the revolutionary history of modern China before the establishment of the People's Republic, James Sheridan's China in Disintegration is a lucid and readable account of the first half of the twentieth century. In addition to those other texts cited below, see Craig Calhoun, Neither Gods nor Emperors: Students and the Struggle for Democracy in China; Louisa Lim, The People's Republic of Amnesia; and the 1995 documentary film, The Gate of Heavenly Peace, which offers an excellent, visual introduction to the events of June 1989 .

I Quoted in Spence, The Gate of Heavenly Peace, I7 $\mathrm{I}^{-} \mathrm{I} 72$.

2 For more on the complexities of this term, see: Tianjian Shi, The Cultural Logic of Politics in Mainland China and Taiwan (Cambridge: Cambridge University Press, 2015), 201; Joseph W. Esherick and Jeffrey N. Wasserstrom, 'Acting Out Democracy: Political Theater in Modern China', The Fournal of Asian Studies 49, no. 4 (1990): 835-865, https://doi.org/10.2307/2058238.

3 From 'To a Certain Woman'. David S.G. Goodman, Beïing Street Voices: The Poetry and Politics of China's Democracy Movement (London: Marion Boyars, I98I), 32.

4 Goodman, Beijing Street Voices, 67. The Four Modernisations were originally formulated by Zhou Enlai, but had been openly adopted by Deng Xiaoping in 1978 . The areas to be modernised were: agriculture, industry, science and technology, and defence.

5 Quoted in Spence, The Gate of Heavenly Peace, 409.

6 MacFarquhar, The Politics of China, 323.

7 Timothy Brook, Quelling the People: The Military Suppression of the Beïing Democracy Movement (California: Stanford University Press, 1998), 48.

8 Bodde, Peking Diary, Iо I.

9 John Pomfret, 'It's "Live Fire! Live Fire!" in Muxidi Battle', Los Angeles Times, 5June 1989 .

Io Orville Schell, Mandate of Heaven: The Legacy of Tiananmen Square and the Next Generation of China's Leaders (New York: Touchstone, 1995), I42.

Invaluable guides to the history of Beijing's walls can be found in: Madeleine Yue Dong's Republican Beijing: The City and its Histories; Wang Jun's Beijing Record; and Susan Naquin's Peking Temples and City Life, I400-I90o, as well as Osvald Sirén's detailed account referenced below.

I The main island had been in British hands since 1842, after the First Opium War; in I898, the Chinese signed a deal leasing the rest of the surrounding lands to Britain.

2 Osvald Sirén, The Walls and Gates of Peking (London: The Bodley Head, 1924), I.

3 La Motte, Peking Dust, I5. 


\section{Sources and notes}

4 La Motte, Peking Dust, i6.

5 Long before, the city had been known as Chang'an, and was the capital city of more than ten imperial dynasties. During the rule of the Tang, one of China's most revered dynasties, it had been ringed by an even longer wall than that which stands today.

6 Kidd, Peking Story, I9I.

7 'Xinhua Insight: What Does China-Style Democracy Matter to Its People?', Xinhua, io March 2017, http://news.xinhuanet.com/english/201703/io/C_i36II8749.htm. Accessed 5January 20i9.

I De Beauvoir, The Long March, I4.

2 Yu, Chang'an Avenue, 266.

3 David Kestembaum and Jacob Goldstein, 'The Secret Document That Transformed China', NPR, 20 January 2012, https://www.npr.org/sec tions/money/2012/oi/20/I45360447/the-secret-document-that-transform ed-china. Accessed 4January 2019.

4 SASAC was established in 2003. In Chinese the name is even more exhausting, at fourteen characters long: in Pinyin, it is the Guówùyuàn Guóyǒu Zīchăn Jiāndū Guănlǐ Wěiyuánhuì.

5 For a cogent account of China's modern economy, see Arthur Kroeber, China's Economy: What Everyone Needs to Know (Oxford: Oxford University Press, 2016).

6 Mary Hooker, Behind the Scenes in Peking (London: John Murray, I9I I), 9I.

I Revolutionary leader Sun Yat-sen had briefly held the post before Yuan.

2 Reginald Fleming Johnston, Twilight in the Forbidden City (Vancouver: Soul Care Publishing, 2009), Kindle edition, location 3224.

3 Feng Youlan, The Hall of Three Pines: An Account of My Life (Honolulu: University of Hawai'i Press, 2000), 47.

4 Lao She, Camel Xiangzi, trans. Shi Xiaojing (Hong Kong: Chinese University Press, 2004), 250.

5 Lao She, Camel Xiangzi, 448.

6 Sima Qian, Records of the Grand Historian, trans. Burton Watson (New York: Columbia University Press, I993), 65.

7 Snow, Red Star, 92-93.

8 Chang and Halliday, Mao: The Unknown Story, 406-407.

9 Li Zhisui, The Private Life of Chairman Mao: The Inside Story of the Man Who Made Modern China (London: Chatto \& Windus, 1994), 94.

Io See the first chapter of Li Zhisui, The Private Life of Chairman Mao. 


\section{Sources and notes}

13

On the history of Tiananmen Square, see Chang-Tai Hung's Mao's New World: Political Culture in the Early People's Republic; Wu Hung's Remaking Beijing: Tiananmen Square and the Creation of a Political Space; Wang Jun's Beijing Record and Shuishan Yu's Chang'an Avenue.

I Marcuse, The Peking Papers, 21.

$2 \mathrm{Yu}$, Chang'an Avenue, 84.

3 Ian Johnson, 'At China's New Museum, History Toes Party Line', New York Times, 3 April 201 I, www.nytimes.com/201 I/04/o4/world/asia/o4museum. html?pagewanted=all. Accessed 4January 2019 .

4 Hung, Mao's New World, I22.

5 'Communists: The Body Snatchers', Time, in October ig6r.

14

On the Boxers, History in Three Keys: The Boxers as Event, Experience, and Myth by Paul Cohen offers a helpful overview of the rebellion and its influence.

I The Alliance was made up of soldiers from the United States, Great Britain, Germany, France, Austro-Hungary, Italy, Russia and Japan. A good proportion of the British troops were in fact from India.

2 Arnold Henry Savage Landor, China and the Allies, vol. 2 (London: Heinemann, I90i), 379 .

3 Mrs Archibald Little, Round About My Peking Garden (London: T. Fisher Unwin, I905), I5.

15

For more on the palace's history, see Geremie R. Barmé's The Forbidden City and Frances Wood's Forbidden City.

I 'The Court Back in Peking', New Tork Times, 8 January I9o2.

2 'The Court's Return', The Times, 7 January I9o2.

3 Sarah Pike Conger, Letters from China (Chicago: A.C. McClurg \& Co., I9o9), 220.

4 The Times, 5 November 1925.

5 Aisin-Gioro Pu Yi, From Emperor to Citizen: The Autobiography of Aisin-Gioro Pu Yi, trans. W.J.F. Jenner (Oxford: Oxford University Press, 1987), 38.

6 Johnston, Twilight in the Forbidden City, 382.

7 Aisin-Gioro, From Emperor to Citizen, I48.

8 Johnston, Twilight in the Forbidden City, 384.

9 Aisin-Gioro, From Emperor to Citizen, I48.

Io Aisin-Gioro, From Emperor to Citizen, I67. Though his wish would not be fulfilled, he did become puppet emperor of the Japanese-controlled state of 


\section{Sources and notes}

Manchukuo in China's north-east between I934 and 1945. Arrested by the Russians at the end of the war, he was subsequently returned to China and kept in a prison camp in Liaoning province. When eventually pardoned by Mao in 1959 , he returned to Beijing. Soon after his arrival, he took a tour of his former palace residence. In From Emperor to Citizen, which was shaped by its ghostwriter to demonstrate that Puyi had been successfully reformed by the CCP, he observes that, in this new Communist era, it seemed the sun was shining on the Forbidden City more brightly than it ever had before.

Aisin-Gioro, From Emperor to Citizen, 77.

I2 Dikötter, The Cultural Revolution, 74.

I3 Barmé, 'Beijing's Bloody August'.

I4 'The Intelligence, Blood and Sweat of the Labouring Masses: The Palace Museum in the Cultural Revolution', China Heritage Quarterly, December 2005, www.chinaheritagequarterly.org/. Accessed 4January 2019.

I5 See Barmé, The Forbidden City, I8-22.

I6 Little, Round About My Peking Garden, i6.

I7 The capital was then returned back to Beijing by the Yongle Emperor, who centred his city around a new palace: the Forbidden City.

Those wishing to learn more of the history of the Legation Quarter will find particularly illuminating: Julia Boyd's A Dance with the Dragon: The Vanished World of Peking's Foreign Colony, and Foreigners Within the Gates: The Legations at Peking by Michael J. Moser and Yeone Wei-Chih Moser. Paul French's Midnight in Peking also offers a vivid portrait of the Legation Quarter in the i93os. Robert Bickers has written extensively on Western involvement in China: see The Scramble for China: Foreign Devils in the Qing Empire, I832-19I4 and Out of China: How the Chinese Ended the Era of Western Domination.

I Little, Round About My Peking Garden, 46.

2 Robert McGhee, How We Got to Pekin: A Narrative of the Campaign in China of I86o (London: Richard Bentley, I862), 287.

3 The Treaty of Tientsin and the Convention of Peking.

4 Snow, Red Star, 40.

5 D.I. Abrikosov, Revelations of a Russian Diplomat (Seattle: University of Washington Press, I964), I63.

6 Peking Dust is also the name given to a dessert of ground chestnuts with whipped cream.

7 Little, Round About My Peking Garden, 34.

8 Bertram Lenox Putnam Weale, Indiscreet Letters From Peking (Shanghai: Kelly and Walsh, I922), 31.

9 Ann Bridge, Four-Part Setting (London: Bloomsbury, 20I4), Kindle edition, location 107 . 


\section{Sources and notes}

Io Conger, Letters from China, 68.

I I Landor, China and the Allies, vol. I, 61-62.

I2 George Kates, The Years That Were Fat: Peking I933-I940 (New York: Harper \& Brothers, I952), I2-I3.

I3 E.J. Hardy, Fohn Chinaman at Home (New York: Charles Scribner's Sons, I905), 9 .

I4 Ann Bridge, Peking Picnic (London: Capuchin Classics, 20Io), $5^{8 .}$

I5 Kates, The Years That Were Fat, $25^{8}$.

I6 The vacated legation buildings would handed over to allies like East Germany, Hungary and Burma, or converted for government use.

For more on Morrison, see his collected two-volume correspondence, Lo HuiMin, ed. The Correspondence of G.E. Morrison; Cyril Pearl's Morrison of Peking; and Lien-Teh Wu's 'Reminiscences of George E. Morrison; and Chinese Abroad'.

I 'Dr G.E. Morrison', The Times, i7 July igoo.

2 Quoted in Cyril Pearl, Morrison of Peking (Sydney: Angus \& Robertson, I967), 272.

3 Claire Roberts, 'George E. Morrison's Studio and Library', China Heritage Quarterly, March 2008, www.chinaheritagequarterly.org/features. php? searchterm $=$ OI3_morrison.inc\&issue $=$ or3. Accessed 4 January 2019.

4 Quoted in Pearl, Morrison of Peking, 30.

5 George Ernest Morrison, An Australian in China: Being the Narrative of a Quiet Fourney across China to Burma (London: Horace Cox, I902), I.

6 Lo Hui-Min, ed. The Correspondence of G.E. Morrison I895-I9I2, Volume One (Cambridge: Cambridge University Press, 2013), 708.

7 Quoted in Pearl, Morrison of Peking, 325.

8 Lo Hui-Min, ed. The Correspondence of G.E. Morrison IgI2-I920, Volume Two, 964 .

For a detailed explanation of the origins of the imperial calendrical systems, see Christopher Cullen's Heavenly Numbers: Astronomy and Authority in Early Imperial China. For more on the Republican calendar, beyond the details offered by more general histories, David Strand's An Unfinished Republic: Leading by Word and Deed in Modern China is helpful. Juliet Bredon and Igor Mitrophanow's The Moon Year is a remarkable and detailed record of the traditions of the lunar calendar. Ian Johnson's The Souls of China: The Return of Religion After Mao offers fascinating insight into the recent return to older ways of thinking in China.

I Henry David Thoreau, Excursions (Boston: Hougton, Mifflin and Company, I863), I72. 


\section{Sources and notes}

2 Charles Baudelaire, The Painter of Modern Life (London: Penguin, 2010), 9.

3 A.B. Freeman-Mitford, The Attaché at Peking (London: Macmillan, I9oo), xxviii.

4 Conger, Letters from China, I72-I73.

5 Quoted in Michaela Fontana, Matteo Ricci: A Jesuit in the Ming Court (Lanham: Rowman and Littlefield, 201 I), 238.

6 In the I930s, they would be removed again and taken for safe keeping to Nanjing.

7 Juliet Bredon, Peking: A Historical and Intimate Description of Its Chief Places of Interest (Shanghai: Kelly and Walsh, I920), 35.

In researching the Grand Canal, China's Imperial Way by Kevin Bishop was a helpful guide. For those interested in the stories of the British embassies in China, see also: J.E. Hoare, Embassies in the East: The Story of the British and Their Embassies in China, Fapan and Korea from I859 to the Present, and M.D. Kandiah, ed. Witness Seminar: The Role and Functions of the British Embassy in Beijing.

I Susan Naquin, Peking Temples and City Life, I40o-Igoo (Berkeley and Los Angeles: University of California Press, 2000), 432 and Nicholas Dennys, Notes for Tourists in the North of China (Hong Kong: A. Shortrede \& Co., I866), I8.

2 D.F. Rennie, Peking and the Pekingese: During the First Year of the British Embassy at Peking (London: John Murray, I865), 22-23.

3 Percy Cradock, Experiences of China (London: John Murray, I999), 22.

43 April ig63.

5 Interestingly, and testifying to the fickleness of memory, some accounts assert that the diplomats watched a different film, also starring Peter Sellers as a criminal: Two Way Stretch.

6 Percy Cradock, 'Interview with Sir Percy Cradock', interview by Malcolm McBain.

7 Juliet Bredon and Igor Mitrophanow, The Moon Year: A Record of Chinese Customs and Festivals (Shanghai: Kelly and Walsh, I927), 65.

8 It had been painted since the photos I had searched out before I visited had been taken, having previously been a dull pink. One of the images showed the pavements outside the embassy covered in debris, evidence of a later tumult on these streets, when in 1999 protestors gathered outside the nearby American Embassy to demonstrate against the NATO bombing of the Chinese Embassy in Belgrade; an accident, but one which was treated as a hostile act by the powers in Beijing. The US ambassador was confined to the embassy, and in the southern city of Chengdu the residence of the US consul was set alight. 


\section{Sources and notes}

9 Jean Vincent, 'Red Guard Attack as Ultimatum Expires', The Times, 23 August 1967 .

I Yu, Chang'an Avenue, I7.

21

I L.C. Arlington and William Lewisohn. In Search of Old Peking (Peking: Henri Vetch, 1935), I.

\section{Epilogue}

I 'Beijing's former industrial complex Shougang district sees sustainable urban regeneration push', Olympic.org, 20 August 2018, https://www.olympic.org/ news/beijing-s-former-industrial-complex-shougang-district-sees-sustainab le-urban-regeneration-push. Accessed 4January 2019. 